\title{
Abstract
}

This paper briefly explores the problematic notion of the 'artist as a social worker' and aims to develop an (ethical) counterpoint to this position via Mouffe's concept of agonism. It begins by tracing some conceptual frameworks that have posited art as an ameliorative force within the public realm, discusses the complications of 'intention' embedded in language, as well as draws attention to the difference between these terms that are often interchangeably. It ends with an exploration of three agonistic artworks, the last being the author's own. It hopes to present a productive counterpoint to the notion of the 'artist as social worker, as well as provide insight to these discussions from a practitioners point of view. 


\section{The Artist As Social Worker Vs. The Artist as Social Wanker ${ }^{1}$}

\section{1) Introduction}

In the UK, over the past two decades, participatory art practices - particularly those funded by Government/Local Authorities - have been employed to address issues such as community cohesion, social inclusion, or to assist groups perceived as marginalised. On one hand, critiques of an instrumentalised application of participatory art have abounded, with Andy Hewitt $(2011)^{2}$, Eleanor Belfiore (2002) ${ }^{3}$ and Sophie Hope $(2012)^{4}$ offering substantial arguments that counter this approach; on the other hand Francois Matterraso $(2011)^{5}$ and Grant Kester $(2004)^{6}$ argue for the possibility of an ameliorative artistic agenda that might align with the notion of the artist as a social worker. This oftproposed praxis within participatory settings however has been less explored from the position of the artist practitioner: as artists working with people, how and why are we interacting with the public, and to what end?

These question requires that we explore the semantics of the terms that grow out of the practice of 'participatory art'. For example, do we define ourselves as a socially engaged artist? A community artist? A community-engaged artist? A community-based artist? Someone with a social practice? A dialogical practice? A relational practice? A participatory artist? An activist artist? A public artist? Someone who does public art? Or someone who just happens works with other people? Each of these terms will connote a different relationship with the public with different desired outcomes and while I would reject a simplification and elision of these terms into a single monolithic and formal practice, I similarly reject the lack of clarity that comes when these terms are used interchangeably. This is particularly vital to discuss when considering the diversity of intent - especially relating to a 'betterment' agenda - that is revealed when interacting with other practitioners within the participatory realm. We may all be 'working with people' but we all seem to be doing it very differently, and for very different reasons.

It is a pressing concern to unravel this confusion because recent years have seen a burgeoning growth of this practice. No longer considered a fringe activity, it receives major attention from policy-makers, institutions, conferences, large funding initiatives, academic journals, as well as the establishment of a number of dedicated MA courses. All this activity guides a professionalisation and instrumentalisation of the practice either from government agencies who might position it as 'social work lite,"7 or from activist agents who might use the practice for their own utopian notions of social betterment, for example activist artists aiming to create a better world based in leftist ideologies. In a world of plurality and diversity, it is therefore a crucial time to reflect on and analyse the multiple different approaches in regards intent.

\section{Art As Social Worker}

Historically, various theorists, practitioners and critics have examined the function of participatory practices and its myriad forms, including Su Braden's Art and People (1978), Owen Kelly's Storming the

\footnotetext{
1The Oxford English Dictionary (OED) defines 'Wanker' as British vulgar slang for: "a contemptible person." It is mostly employed as a form of generalised abuse, with specific reference - albeit not literally - to masturbation. However, I employ it in direct reference to the notion of 'contempt' in that a contem ptible person is one who might critique established and accepted modes of power, as in: 'contempt of court'. A wanker, in this reading, is then the one who intentionally operates to unravel and challenge accepted social and cultural patterns.

${ }^{2}$ Hewitt, A. (2011) 'Privatising the Public: Three rhetorics of art's public good in 'Third Way' cultural policy' in Art \& the Public Sphere, $1: 1$, pp.19-36

${ }^{3}$ Belfiore, E. (2002) 'Art as a means of alleviating social exclusion: Does it reallywork? A critique of instrumental cultural policies and social impact studies in the UK' International Journal of Cultural Policy, 8:1. pp. 91 - 106.

${ }^{4}$ Hope, S. (2012) Participating in the 'Wrong' Way? Practice Based Research into Cultural Democracyand the Commissioning of Art to Effect Social Change. PhD Thesis. University of London. London.

${ }^{5}$ Matarasso, F. (2011) 'All in this together': The depoliticisation of communityart in Britain, 1970-2011, Community, Art, Power: Essays from ICAF. Rotterdam: ICAF.

${ }^{6}$ Kester, G. (2004) Conversation Pieces: Community and Communication in Modern Art. Berkeley and Los Angeles: University of California Press.

${ }^{7}$ See for example, Belfiore, E. \& Bennett, O. (2007) Rethinking The Social Impacts of The Arts. International Journal of Cultural Policy, 13:2. pp. $135-151$
} 
Citadels (1984), Suzanne Lacy's New Genre Public Art(1995), Conversations Pieces by Grant Kester (2004) and Artificial Hells by Claire Bishop (2012), to name a few. Problematically, however, each has seem to claim a 'true' definition of the practice and its purpose/function, and this has led to a series of spats $^{8}$ and 'stooshies ${ }^{\prime 9}$ which have further divided the field into tribes and sides. Through-out all of these theorisations and splits, however, the main underlying theme pertains to the relationship participatory art projects have with notions of amelioration. Most often quoted in regards to this question, Grant Kester writes of the link between the artist and the social worker:

Both the community artist and the social worker possess a set of skills (bureaucratic, diagnostic, aesthetic/expressive, and so forth) and have access to public and private funding (through grants writing, official status, and institutional sponsorship) with the goal of bringing about some transformation in the condition of individuals who are presumed to be in need. ${ }^{10}$

Kester's suggestion to elide the roles of social worker and that of the artist due to shared goals - i.e., bringing around transformation to those 'in need' - reveals the common assumption about artists working in participatory contexts: that we artists working with people are/should be committed to an ameliorative agenda. This elision is however problematic to me for two reasons: the first is an issue of 'practicalities' and the second is an issue of 'intent'.

Before exploring these two concerns, however, it is useful to define the 'Social Worker'. The International Federation of Social Work defines the work as a "practice-based profession and an academic discipline that promotes social change and development, social cohesion, and the empowerment and liberation of people." ${ }^{11}$ In the UK, it refers to someone employed to provide social services (especially to the disadvantaged). ${ }^{12}$

I have emphasised two key words in the above paragraph - 'profession' and 'employed' - as they provide a clue to my first concern regarding 'practicalities'. A profession suggests a practice with specialised training, formalised schools of thought and education. Similarly the notion of employed suggests someone who is part of a larger organisation with structures, hierarchies, institutional policies and various different levels of support. Therefore, to conduct social work requires specialised training, regular funding, inter-agency co-operation, systems of support and guiding policy/theory in order for it to achieve its goal. In contrast, an artist is (more-often-than-not) a single individual without specialised social work training or institutional support - we have been train to make art not to do social work; an artist is rarely regularly employed in a structured system; nor, indeed, can artists be said to have a cohesive identity that helps define him/her. So, on a practical level it would be highly problematic to assume the artist could effectively or practically conduct the practical business of social work without the formal structures of its profession.

Similarly, and regarding my secondary concern of intention, social work is often run out of governmental agencies or funded by them, thereby operating within a public, democratically-elected mandate that gives it the ethical framework to act on/with/for disadvantaged people (however problematic that democracy is). (Granted, it is more problematic for my argument that there are wholly private organisations which run aspects of social work, but I would argue these are the exceptions rather than

\footnotetext{
${ }^{8}$ One of the more public being the Kester Vs. Bishop on the pages of Artforum in 2006. For a selected example of the fallout of this 'spat', see: 'Metamute', 10 May 2007, http://www.metamute.org/editorial/articles/zombie-nation. (Available online Accessed 18 December 2014) or 'Impex', May 2006, http://www.impex-info.org/text/texts ibz eng 05.html. (Available onlineAccessed 18 December 2014) or 'Incubate', June 2011, http://incubate-chicago.org/wp-content/ uploads/2011/04/InCUBATEWhat-do-Artists-Know.pdf. (Available online - Accessed 18 December 2014)

${ }^{9}$ Stevenson, D. (2014) 'Tartan and tantrums: critical reflections on the Creative Scotland "stooshie"'. Cultural Trends, Volume 23, Issue 3, 2014. Special Issue: Scottish Cultural Policy. P 178-187. 'Stooshie' is a scottish term for an argument; hearty discussion.

${ }^{10}$ Kester, G. . Aesthetic Evangelists: Conversion and Empowerment in Contemporary Community Art. Afterimage 22, January 1995

${ }^{11}$ The International Federation of Social Work (n.d.) http://ifsw.org/get-involved/global-definition-of-social-work/ (Available Online - Accessed Feb 10th, 2017)

${ }_{12}$ The International Federation of Social Work (n.d.) http://ifsw.org/get-involved/global-definition-of-social-work/ (Available Online - Accessed Feb 10th, 2017)
} 
the norm.) An artist, by contrast has no public mandate that justifies him/her to act upon/with/for a public group of people. The artist has rarely been elected by democratic remits, and indeed often commissioned/employed by private charities/art organisations that require specific social engineering outcomes. ${ }^{13}$ This therefore makes the artist's actions of engaging with the public ethically problematic at worst, and paternalistic at best.

This is also illustrated by (and a concern of) the 'institutional intent' of art projects within participatory settings in regards to social betterment. The social worker operates within an institutional setting whose policy should aim to be holistic in regards to "social change and development"14; has strategies about how and what needs to be done to achieve their social work goals - it may be different from other social workers and there may be a plethora of perspectives of how to achieve goals, but there are a set of decided upon policies within agencies that guide a social worker's project. Again, in contrast, an artist (if not working alone) does so from with a gallery/museum context, which has multiple intentions, but primarily is concerned 'art' and as such, an artist working on a 'social betterment' agenda either becomes a tack-on or an addendum to a wider programme at best, or at worst, an ersatz government employee enacting propaganda via publicly funded art gallery outreach programmes.

The artist is therefore a poor substitute for a social worker and, logically, we could infer that the Social Worker might also be a poor substitute for an artist. Indeed, it should be clarified that my argument does not necessarily deny that a social worker might also be an excellent artist, or an artist might also make a great social worker: my point is about the collapsing of the intentions of their respective professional intentions. To collapse the fields into one devalues both. It disavows the unique specialisms in each - art's ability to ask deep and probing questions and social works ability to be wholly committed to social betterment. Nor does this argument wish to suggest that the separate worlds can never collide, only that it would be dangerous to replace one with the other because they would both be made weaker - not stronger - and would leads us down the instrumentalist's path where the artist is the state's cheaper option to proper and appropriate social work. See Andy Hewitt's excellent Privatizing the public: Three rhetorics of art's public good in 'Third Way' cultural policy (2011) ${ }^{15}$ for further reading on this topic.

\section{Semantics}

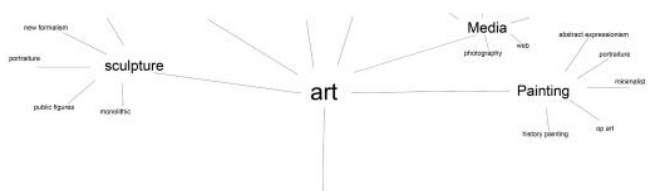

PARTICIPATION

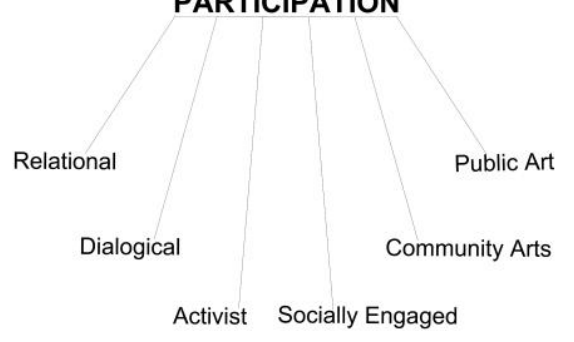

Diagram 1.1: Anthony Schrag, Branch Diagram of 'Participatory Art Genres'. 2016. Venn Diagram. Variable. (C) The Artist.

\footnotetext{
${ }^{13}$ For example, John McLean asks how: "can art institutions perform anysort of critical function when they are so integrated into the workings of the government to the extent they need to provide evidence of their benefit to the economy, urban regeneration and social inclusion?" (J. Maclean. (2012) The Open Council: a practice led enquiry into improvisation and the self-institution. PhD Thesis. Newcastle-upon-Tyne. Newcastle University. See also: A. Schrag (2016) Agonistic Tendencies: the role of conflict within institutionally supported participatory art projects. PhD Thesis. Newcastle-upon-Tyne: Newcastle University.)

14 The International Federation of Social Work (n.d.) http://ifsw.org/get-involved/global-definition-of-social-work/ (Available Online - Accessed Feb 10th, 2017)

${ }^{15}$ Hewitt, A. (2011) 'Privatising the Public: Three rhetorics of art's public good in 'Third Way' cultural policy' in Art \& the Public Sphere, 1:1, pp. 19-36.
} 
Historically, the practice of working with people is not new: 'culture' has always been done with people, and the criteria of what makes 'participation' a unique field is fairly arbitrary. One could easily argue all art is participatory to some degree. Consider the 1553 painting The Ambassadors by Hans Holbein, in which only viewers standing at a certain angle to the canvas can see a trompe l'oeil skull, while others merely see a smudge of paint and colours. This could be said to illustrate that Holbein was not only aware of the viewing public's position, but also developed context specific and relational experiences with him/her, much like contemporary notions of participatory art. However, as a working definition of participatory practices, it is not a useful one as it ignores the history specific to our historical understanding of 'working with people' and provides a clue of further research vital to the understanding of this practice. This conceptualization also ignores the nuances of intent, and so to unravel further the absurdity of 'social betterment through art' it is important that I provide my own distinctions of what is meant by 'participatory art' and its various linked terms.

While there are variations and additional verbs to clarify meanings (i.e., community-based vs community-engaged: one signifying a locational practice and the other signifying an engagement with from an external body) broadly, the main terms used when speaking about 'working with people' are: Community Arts, Activism Art, Socially Engaged Art, Dialogic Art, Relational Art, and Public Art. I have excluded 'participatory' practices in this list of definitions as this seems to be the over-arching terminology that defines the practice as a whole, in the same way that 'painting' incorporates the many different type of paintings. Below, I give a brief description of each of these sub-genres, and have also included an example after each.

1) Community Arts: Stemming from the Community Arts Movement (CAM), this 'older' form of a participatory practice came to the fore in the 1970 s and ' 80 s as a practice rooted in the artist working in collaboration with communities, which were usually those perceived as being in a disadvantaged state (poverty, substance abuse, etc.) and whom artists "sought to empower though participatory creative practice."16 It often resulted in community-based and communityconstructed objects - i.e. community murals/mosaics similar to the work developed by David Harding during his time as the Town Artist (1968-1978) in Glenrothes. ${ }^{17}$ Here, the community is the focus, and the quality of the art produced is less of a concern than the expressive and political nature of the process.

2) Socially Engaged Practice (SEP): SEP is in line with notions of 'social betterment', like Community Arts, but is also concerned with the systems that sustain community oppression. However, it is less concerned with direct political action (like Activist Art below) and more with a commitment to social change and development via consciousness-raising. It often, though not necessarily, results in public events authored by the artist, in collaboration with participants. An example of this is Jardín Botánico de Culiacán's Palas por Pistolas (2007) in which the artist collected guns from a community and then melted them into steel to fabricate shovels that he then used with the community to dig holes in order to plant trees. ${ }^{18} \mathrm{Here}$, the art plays a central role both in the process, and is given equal attention as the political, social processes.

3) Activist Art: this practice is strongly aligned with leftist politics and dedicated to the emancipation of participants and the liberation of the society via a critique of oppressive (Capitalist and Neoliberal) regimes, with a primary concern being direct intervention into power structures. It is primarily event-based, although it can assume other means, such as posters, graffiti, publications, etc.. An example of this would be The Clandestine Insurgent Rebel Clown Army who merge clowning with civil disobedience to enact non-violent direct action in situations of protest. ${ }^{19}$ Here the art is in the employ of direct social change and regime critique, and serves that purpose above all else.

\footnotetext{
${ }^{16}$ Bishop, C. (2012) Artificial Hells: Participatory Art and the Politics of Spectatorship. London: Verso. p. 177.

${ }_{17}$ Harding, D. (n.d.) 'The Town Artist'. Undated, David Harding Website: www.davidharding.net/townartist, (Available online 16 October 2014).

18 'Palas Por Pistolas'. (n.d.) http://pedroreyes.net/palasporpistolas.php, (Available online - Accessed 16 October 2014).

19 'Clandestine Insurgent Rebel Clown Army'. (n.d.) http://beautifultrouble.org/case/clandestine-insurgent-rebel-clown-army/

(Available online-Accessed 11 December 2014)
} 
4) Dialogic: associated with Grant Kester, this way of working is fundamentally concerned with artworks framed as conversation and exchange, and configures the public not as an 'audience' but rather as a collaborator. It aims to avoid the paternalism which might be engendered via an 'outsider' working within a community that is not his/her own and demands the power structures to be more egalitarian between the artist and the participant, where both can be influenced by the other. It often results in a plethora of outputs, both gallery-based and public. The work of Oda Projesi is a good example of this work. In this project, three artists have been collaborating with their neighbours in an area of Istanbul developing workshops, drawing sessions, discussion groups, community picnics, parades and other community events as way to provide space for dialogue and discussion on topics that were important to their lives, including community politics. ${ }^{20}$ This approach can be often seen to be similar to the Community Art Movement (CAM), however it differs in the relationship it has to the 'art institution: whereas CAM was purposefully sited outside the art world, Dialogical works have a more blurred relationship to contemporary art. For example: Oda Projesi hired a room to exhibit artworks in a traditional gallery format, and exhibits the documents of their time with their Neighbours in other galleries and art contexts out with of that neighbourhood. ${ }^{21}$ In other words, unlike CAM there is not an intentional break from the traditional art institution, and dialogical artists are "interdisciplinary. It operates 'between' discourses (art and activism, for example) and between institutions (the gallery and the community centre or the housing block)."22 Unlike SEP, too, the art produced often seems to have more importance than the political and social processes.

5) Relational Aesthetics: a practice described by Nicolas Bourriaud that is based within the (conceptual/physical) structures of art institutions and sought new, more social ways of engaging with publics other than with traditional object-base works. They are primarily structural and/or events-based artworks, and occur primarily within institutional frameworks - i.e. gallery constructs and biennials. An example of this would be Liam Gillick's designed environments staged in galleries that encourage and frame a variety of social relationships. ${ }^{23}$ Here, the art world structures are not only apparent, but also dominant: consider that many of these works occur inside museums/galleries and engage with people on those terms, rather than outside, in the public/social sphere.

6) Public Art: these are works that are funded or approved by public bodies, such a Local Authorities and (while not exclusively) they are more-often-than-not sculptural or semipermanent. They primarily iterate a public concern and/or interest and often result in objects placed in the public sphere. An example of this would be Antony Gormley's Angel of the North (1998). ${ }^{24}$ Sometimes referred to as 'plop art', it has varying degrees of dialogue with the communities in which is placed, but often are 'adopted-and-adapted' by communities after installation, sometimes in humorous and cheeky modes: Consider the case of the Equestrian Statue of Wellington outside the Gallery of Modern Art (Glasgow) in which - every weekend someone will climb up this 5 meter structure to place a traffic cone on the statue's head and every Monday, the Council will take it down, in an endless illustrating a performance of the complicated nuance of ownership of public space. While obviously not part of the original sculpture's intention, there is scope for research to explore the participatory nature of these works in regards to how they are re-claimed by citizens.

\footnotetext{
20 'Oda Projesi' (2007). Oda Projesi Website, http://odaprojesi.blogspot.co.uk/. (Available online - Accessed 11 December 2014).

${ }^{21}$ Coulter-Smith, G. 2006 'Deconstructing Installation Art' Installation Art Website

http://www.installationart.net/Chapter6Conclusion/conclusion04.html. (Available online - Accessed 14 March 2015).

${ }_{22}$ Kester, G. . (2000) 'Dialogical Aes thetics: A Critical Framework For Littoral Art' Variant Magazine. Glas gow. Variant, Issue 9. Special Supplement.

23 'Liam Gillick' (n.d.) Tate Website, http://www.tate.org.uk/art/artists/liam -gillick-2592. (Available online-Accessed 18 May, 2015).

24 'Angel Of The North' (2015) Gateshead Government Website,

http://www.gateshead.gov.uk/Leisure\%20and\%20Culture/attractions/Angel/Home.aspx. (Available online - Accessed 11 December 2014)
} 


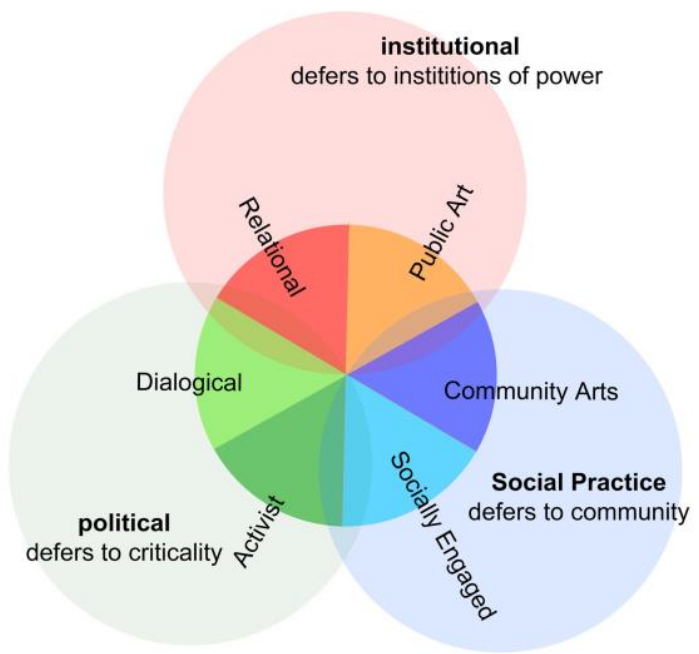

Diagram 1.2: Anthony Schrag. Interacting Venn Diagram of Participatory Art Genres, and Their Derivative Power Sources. 2016. Venn Diagram. Variable. (C) The Artist.

These 6 terms require a subsequent breakdown to further clarify their intent. This intent can be illustrated by the diagram above. The diagram features the above terms and their 'domain.' By domain, I mean that which gives the work its meaning; the frame through which the work's presence in this world is justified. As above, this does not constitute a binding or rigid structure, but how I am defining this practice in regards to how I see it operate, as a practitioner and researcher in the field.

Within the diagram, the definitions are clustered into pairs, each pair sitting into one of three spheres: institutional, political or social practice. Within the Institutional sphere, the working processes Relational and Public art - defer to the institutions of power that define the works intention: Public art is funded and ordained by public bodies and Relational works are concerned with new types of (public) relationships within the art gallery/museum realm. Both defaults to the power of the authority that funds/organises them, and therefore the intent of their work is to recapitulate and reinforce that power, either of the public institution (i.e., local government) or to the institution of art (museum/gallery). The general mood of these works are serious and deferential.

The Social Practice sphere illustrates that both Socially Engaged art and Community art defer to a notion of 'community'25 and their needs and desires. The works do not necessarily therefore contain any criticality of the systems that sustain the social sphere, but instead work from within those systems and the intent is to sustain - and defer to the construction of - community. The general sentiment of these works are nice and convivial.

The Political sphere defers to a criticality via Activism art and Dialogical artworks. The intent within them is to critique the politics that sustain oppression via either direct action (activism) or exploring a mutual line of inquiry between artists and participants which initiates a transformation for those engaged (dialogue). While not wholly replicating Grant Kester's Dialogical Aesthetics, Dialogic intent is similar in that that the works created aim to find a consensual meeting point that can transform society into a more egalitarian condition. The general mood of these works is politically 'charged'

There is one last clarification in regards to these definitions: two more 'spheres' of intent need to be included. They cannot be represented visually, as they are both the substrate on which these circles are placed and can be present (and/or absent) in all spheres: these circles represent Education and Participation.

${ }^{25}$ I recognise this is a highlycontested term. 


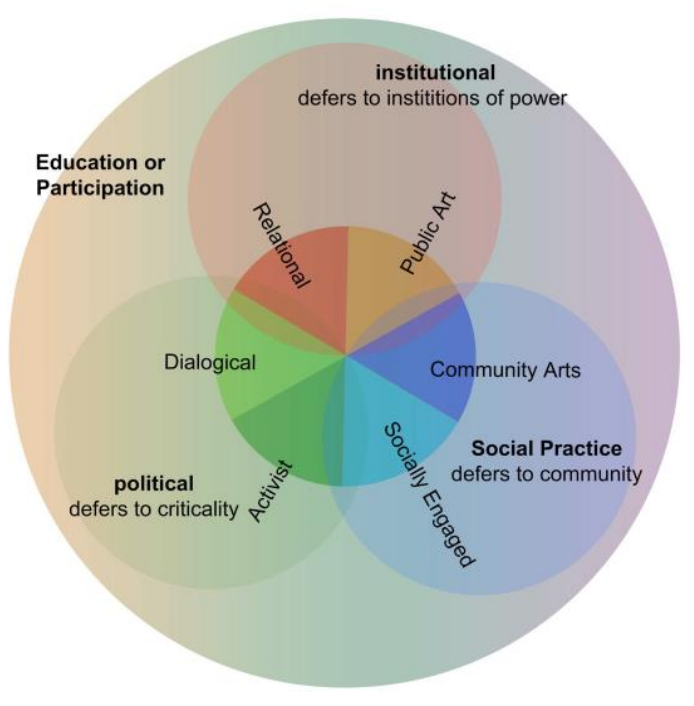

Diagram 1.3: Education OR Participation as part of Interacting Venn Diagram of Participatory Art Genres, and Their Derivative Power Sources. 2016. Venn Diagram. Variable. (C) The Artist.

These two spheres exist in constant tension, and are the very fabric of the question of intent when working with people: does an artist/institution/community want to engage in a 'participatory' project or and 'education' project? The difference is subtle but incredibly important. Education is a process of 'knowing/unknowing;' a power system of knowledge; an assimilation of 'those who don't participate' into 'normal' structures via hierarchies such as schools and correctional facilities (i.e., prisons) into 'good citizens'. Participation however suggests a more collaborative and egalitarian process that has no premeditated outcomes; it is a process in-and-of-itself not necessarily focused on any outcome other than participation. While the two are often collapsed, and complexly interwoven - no doubt participation involves some education and vice versa - the clarification of whether a project is educational or participatory will reveal its intent either as a form of social engineering to "construct civic identities"26 amenable to the state, or if it is a true collaborative approach that is based on a dialogic, relational model with a mutual, shared and common inquiry. Indeed, knowing in which of these spheres of intent an art work sits is the very crux of deciphering how the 'social betterment' agenda is being employed, and to what end.

To decipher this, I now present a model of practice which is able to clarify intentions. I refer to it as a 'conflictual participatory practice'; or employing an agonistic approach. 'Agonism' derives from Chantal Mouffe philosophy applied to critique power, but it does so not as a binary and oppositional enemy, but as an adversary: something/someone that is ultimately aiming for the same goal as another, but whose utopias may very well be incompatible. As a method of working, it closely aligned to a 'dialogic' practice, as above, but frames itself via dialogic dissensus in order to reveal the intent of a project first and foremost, both in content of the work but also in its mode of participation.

It is important to differentiate between the dialogic intent of an agonistic approach and the dialogic intent of Grant Kester's Dialogical Aesthetics. The difference lies in another of Mouffe's conceptualisations of Politics versus the Political. ${ }^{27}$ The agonistic intent is political, whereas Dialogical Aesthetics does politics. This debate is briefly clarified thus: politics replicates a 'right vs wrong' dichotomy, and critical of a specific oppressive politics and seeks to create the world in a more egalitarian manner via replicating party politics (i.e., Democrat Vs. Republican; Labour Vs. Tory etc). ${ }^{28}$ Whereas political intent is critical of power in all its forms and manifestations, not with manifesting a specific utopia; its aim is unravelling and revealing political hegemonies. In this manner, the intent an agonistic approach is to expose the ubiquitous political structures of life and living, rather than fight in the name of specific politics. Situating art as a tool for social betterment therefore falls into a 'politics'

\footnotetext{
${ }^{26}$ Vickery, J. (2007) The Emergence of Culture-led Regeneration:A policy concept and its discontents. Centre for Cultural Policy Studies, Coventry: University of Warwick.

${ }^{27}$ Mouffe, C. (2013) Agonistics: Thinking The World Politically. London. Verso. p. 3

${ }^{28}$ See for example Kester, G. . (2004) Conversation Pieces: Communityand Communication in Modern Art. Berkeley and Los Angeles, University of California Press. pp 69 - 81
} 
frame because it suggests there is a 'right' way of being and a 'wrong' way of making the social 'better'. The general feel of these works are confrontational and uncomfortable because they exist at the intersection between the spheres of intent, and complicate a simplified instrumentalised approach to

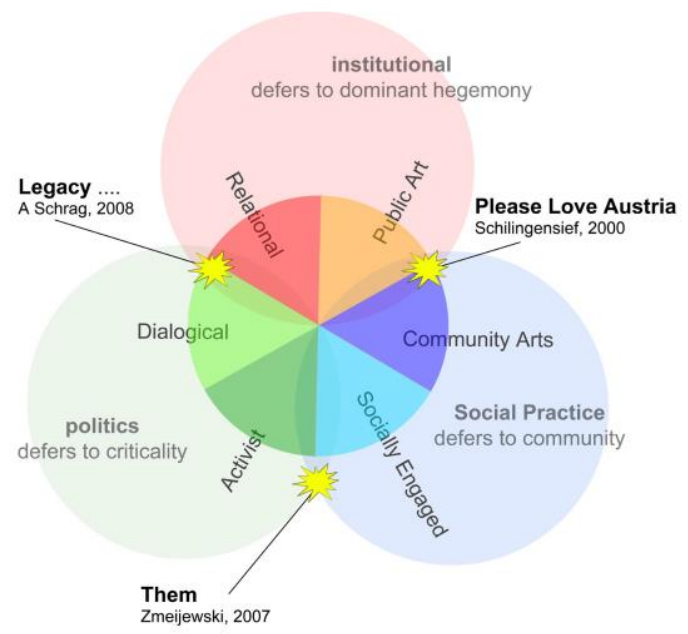

working with people.

Diagram 1.4: Anthony Schrag. Location of Agonistic Artworks as part of Interacting Venn Diagram of Participatory Art Genres, and Their Derivative Power Sources. 2016. Venn Diagram. Variable. (C) The Artist.

\section{Agonistic Participatory Practices}

I now present three examples of agonistic works which explore this particular framing of art within the social realm: Artur Zmijewski's Them, Christoph Schlingensief's Please Love Austria, and my own work, Legacy of City Arts Projects.

Artur Zmijewski's Them (2007) is an authored documentary film of an event organised by the artist to explore notions of collective identity, nationalism, co-operation and interaction between opposing ideological groups in his native Poland:

Zmijewski came of age bombarded by opposing ideologies. At art school, he and his peers were encouraged to finish each other's work, a sure-fire method to get students thinking about how meaning takes shape. A recurring concern throughout his work, Zmijewski would explicitly put this strategy to the test in his grimly funny 2007 piece Them. Four groups - Polish nationalists, Catholics, Jews and socialists - first make posters symbolising their beliefs and are then invited to amend each other's handiwork. After much ripping and graffiti-ing, the groups turn on each other, eventually burning the work and throwing it out of the window. Left with nothing, they seem to have reached an impasse, or possibly, less pessimistically, a place where, free of insignia, they might consider their situation anew. ${ }^{29}$

The work, while problematically edited, as Zmijewski himself admits, ${ }^{30}$ presents a situation of conflict rather than participation. Indeed the very notion of a participatory project is called into question by the introduction of active opposition between the social groups.

\footnotetext{
${ }^{29}$ Sherwin, S. '(2010) Artist of the Week 101: Artur Zmijewski' The Guardian Website http://www.theguardian.com/artanddesign/2010/aug/18/artist-of-week-artur-zmijewski (Available Online - Accessed May 15, 2016)

${ }^{30}$ Bishop, C. \& Tramontana, S. (eds.), (2009) Double Agent, London: ICA. pp. 99-106
} 
Here, Zmijewski embodies agonistic approach by organising a real-life situation wherein the conventions of participation - a situation where people work together or collaborate - are disregarded and ignored: He actively presents a situation wherein conflict might arise. The notion of working together is challenged, as he reveals this impossibility of that intention. It is, however, only through the mutual recognition of that impossibility that the participants 'might consider their situation anew. ${ }^{31}$

Here Zmijewski is in contempt of the nature of community participation itself, and as such is located between the social and political spheres of intent. He has complicated both fields, and in doing so he reveals the true complexity of a multiple and diverse society, and through which he presents the only possibility of a real and lasting social transformation. Imagine, for example, how a 'social betterment' artist might have found a way to work with such diverse groups and what insights (or not) they would have reached via encouraging consensus, rather than the illumination of the dissensus that actually existed. Therefore, via his agonistic approach Zmijewski complicated participation to explore the limits of democratic possibilities within the social sphere. The artwork did not collapse the possibilities into a single utopia, but rather was productive in its revelation of dissensus.

Another work that applies an agonistic participation approach is Christoph Schlingensief's Please Love Austria (2000). In this work, Schlingensief placed a shipping container in the centre of Vienna. It rigged with webcams and contained 12 illegal 'immigrants' which the public could 'vote out' via the internet. The project lasted six days. Described as a 'reality TV event' by Schlingensief himself, the project is explained on his website:

Amid intense public interest, twelve participants introduced... as asylum-seekers spend one week in a cordoned-off, CCTVed shipping container complex next to the Vienna opera house. Blue flags representing Austria's far-right populist FPÖ party are hoisted on top of a container.

As onlookers applaud ambiguously, a sign bearing the slogan "Ausländer raus" ("Foreigners out") is unveiled and then attached to the container together with the logo of the Kronenzeitung, Austria's biggest-selling tabloid. Excerpts from speeches by FPÖ chairman Jörg Haider resound across Herbert-von-Karajan-Platz. With clear references to the BIG BROTHER TV show, the Austrian population are asked to phone in and vote out inhabitants, the two least popular of which are ejected each day. Votes can also be cast via the Internet, where Webfreetv broadcasts events from the container live - 24 hours a day for a period of six days.

The square is regularly visited by high-profile "patrons" such as acclaimed writer Elfriede Jelinek and political figures Daniel Cohn-Bendit and Gregor Gysi, who then obligingly provide status reports.

Every morning at eight o'clock, two residents are ejected from the container to be deported to their native country. The winner can look forward to a cash prize and the prospect, depending on the availability of volunteers, of Austrian citizenship through marriage. ${ }^{32}$

Schlingensief himself played ringleader to this circus, standing next to or on-top of the counter with a megaphone enjoining people to participate in voting out who they felt was not worth being a citizen; interviewing political leaders; interacting with the large crowds that gathered outside the container that either admired or denounced the 'installation' depending on their own personal politics. A group of activists attempt to break into the container to 'free' the immigrants, and police were involved in several scuffles between the various political persuasions. Crucially, however, the work never presented the politics of this act as 'good' or 'bad,' but instead actively revealed them and in this instance, Schlingensief problematised the dominant hegemony by giving voice to alternative perspectives on the

\footnotetext{
${ }^{31}$ Sherwin, S. '(2010) Artist of the Week 101: Artur Zmijewski‘ The Guardian Website http://www.theguardian.com/artanddesign/2010/aug/18/artist-of-week-artur-zmijewski (Available Online - Accessed May 15, 2016)

${ }^{32}$ Jessen, J. (n.d) ('Please Love Austria'. Schlingensief Website www.schlingensief.com (Available Online - Accessed Decmber 2, 2014)
} 
matter. He collapsed the politics and different ideological approaches of immigration into a singular spectacle that revealed, in visceral and telling manner, the structures of the politics, the relationship between the media and governmental policies, and the nature of participatory democracy. This work is therefore located between the 'institutional' and the 'social' spheres of intent as he has complicated the relationship between political power and society.

The intention here was not to kowtow to specific ideologies and stereotypes of participatory art's supposed leftist agenda, but rather maintain a frustrating political ambiguity. He was disobedient to established codes of art and politics, and in this way complicated and problematised a simplistic thinking (politics) in favour of a more realistic reflection of a pluralistic world. Most illuminatingly, however, was that he disregarded the ethics of involving a disempowered group (immigrants) in the manner in which he did. In doing so, however, he exposed the population's own complicity in their relationship with racist politics and caused more discussion and debate about Austrian immigration policies than the existence of a real and well-established detention centre, only a few miles from his theatrical re-staging.

Lastly, a project of my own. In 2007 The Gallery of Modern Art (GoMA) in Glasgow held their third Social Justice programme. This was a bi-annual programme exploring human rights and contemporary arts with specific interest in those subjects that were relevant to Glasgow. The theme of the third biennial was to explore sectarianism (Blind Faith, 2007), perceived to be a major social blight in the city, exacerbated by religious, geographical and class divisions.

Each of the Social Justice programmes comprised a large exhibition and many smaller outreach and education projects that were more 'participatory' in nature, intended to engage with various 'non-art' audiences for whom the topic was perceived as relevant. I was selected to work with identified young people in the east of Glasgow to develop art projects that might have an ameliorative effect on the participants via a creative inquiry into sectarianism. This 'orthopaedic approach'33 was apparent in the funding applications: "The emphasis throughout the residency will be one of social inclusion, with [the artist] working particularly with groups from Glasgow's communities that have high levels of deprivation, and little access to the arts, in line with the Council's policy of delivering its services equally to all" 34 and "by using the power of contemporary art to challenge public attitudes we believe we can contribute to the development of a more tolerant society." 35

Once the project began it quickly became apparent that the issues faced by the young people were only superficially related to sectarianism but due to systemic poverty and I felt I could not sufficiently adjust this social inequality within the 6 month timeframe, or even at all. I also realised that I was being located as an ersatz social worker, in the sense that the goals of the project located in a specific 'social inclusion' ideology and its neoliberal approach.

The participants had been perceived as somehow flawed and the community in need of fixing, and the institution (the city council-funded GoMA) employed its dominant position to address these flaws via the 'transformative potential of art'. In this case art was being used as a tool of social renewal without analysis of what this 'renewal' meant, to whom, why it was necessary and who might benefit. Hewitt expands this notion and suggests the social inclusion approach pre-conceives a 'correct way of being' that the art project is required to socially engineer and that this denies the agency of community participants, as well as any pre-existing, indigenous culture of the community involved. ${ }^{36}$

Additionally, in being hired by the institution, I felt indebted to GoMA and its participation aims, and raises a question as to how artists retain a sense of criticality when one's job is ultimately to support the

\footnotetext{
${ }^{33}$ Kester, G. . (2004) Conversation Pieces: Community and Communication in Modern Art. Berkeley and Los Angeles: University of California Press, p.88.

34 Submitted to Author by main applicant, Social Inclusion Officer Katie Bruce, Oct 2012. Drawn from funding application issued by Scottish Arts Council, 2006 (Emphas is added)

${ }^{35}$ Submitted to Author by main applicant, Social Inclusion Officer Katie Bruce, Oct 2012. Drawn from funding application issued by Scottish Arts Council, 2006 (Emphasis added)

${ }^{36}$ Hewitt, A. (2011) 'Privatising the Public: Three rhetorics of art's public good in 'Third Way' cultural policy' in Art \& the Public Sphere, $1: 1$, pp. $19-36$.
} 
institution's agenda. I felt there was a disjunction between the intentions of the institution and the lived reality of the identified community.

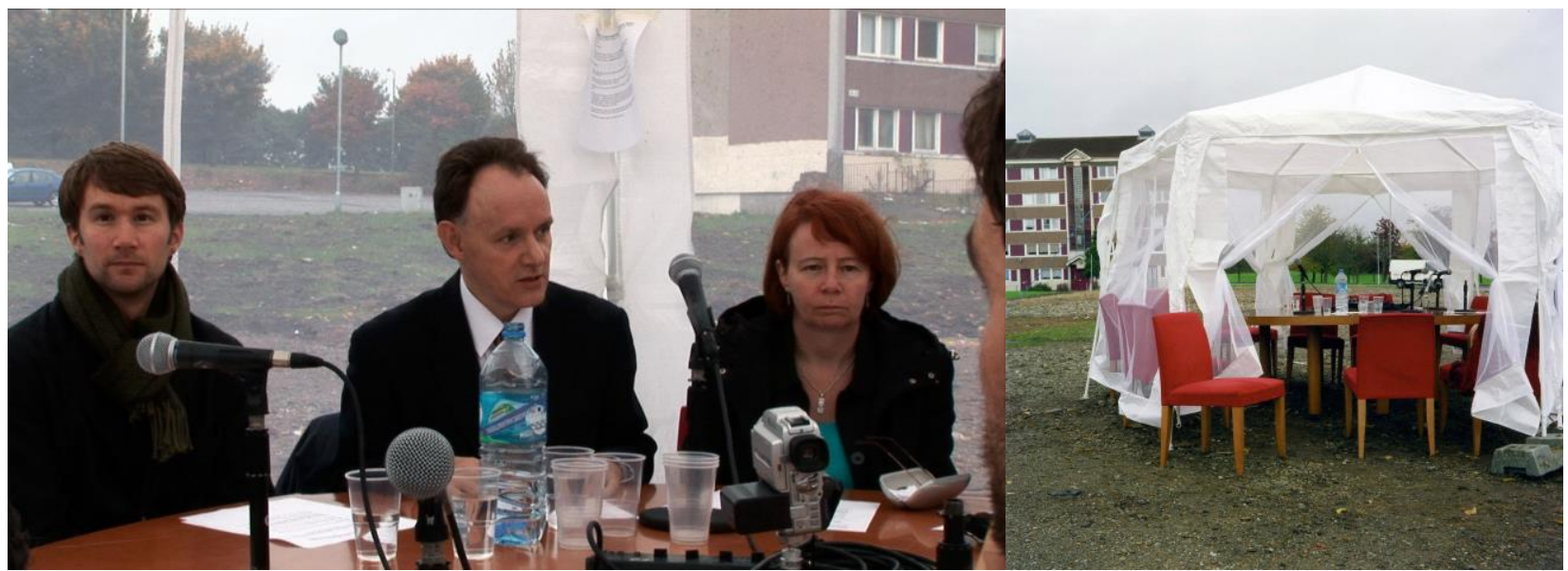

Image 1.1: Photographic documentation of Legacy Of City Arts Projects, A Schrag, 2007. Easterhouse, Glasgow.

Therefore, instead of attempting an orthopaedic intervention, I focused on the Institution that commissioned the project, inviting the curators, advisory board, the civil servants and representatives from the charitable trust who guided the project, to come to GoMA to discuss the mismatch between "place and policy." 37 However, when these people arrived, expecting a meeting in the neoclassical art gallery, I bundled them into waiting taxis and drove them out to the east of Glasgow, effectively 'kidnapping' them, and taking them to a muddy field, where a table and chairs waited, surrounded by the residents of the very housing estate they had expected me to 'fix'. The intention was to have the proposed discussion, but have it in a place that was away from the marble and neoclassical structures of power and instead in the very real, disrupt-able, cold and noisy location that was the everyday reality of those citizens involved with the project.

The work was called The Legacy of City Arts Projects (2007) and it enacted a type of 'contempt of court' in that the event went against established modes of a traditional participatory practice (i.e., the focus of the work was 'with' the institution, rather than the public) thus being disobedient to those structures. It also upset the dominant hegemony by disregarding the traditional deference paid to curators, civil servants and trust representatives in favour of an alternative social approach. It was therefore complicating the intention of the institution and the political nature of participation, and sits between these two spheres, and situation ignored the structures that are required for a smooth social functioning, and through this, the flaws of the intentions - the enacted policies - could be revealed and critiqued effectively. If I had undertaken the 'social betterment' approach working on with the participants of the housing estates, I would have never been able to reveal the original intentions of the commission and how it might be flawed and/or ethically problematic in regards to myself, the citizens of Glasgow and the institution.

\section{Conclusion}

The three works discussed all shared an intention to unravel dominant hegemonies and not defer to politics, but rather reveal the power dynamics at play. They function agonistically as suggested by Chantal Mouffe:

Those [artists] who advocate the creation of agonistic public spaces where the objective is to unveil everything that is repressed by the dominant consensus are going to envisage a relation between artistic practices and their public in a very different way than those whose objective is the creation of consensus - even if that consensus is considered critical consensus. According to the agonistic approach, critical art is art that

${ }^{37}$ Quote from Mark O'Neill, then Head of Museums of Culture and Sport Glasgow, at Legacy of City Arts Projects event. October, 2008. 
forms a dissensus - that makes visible what the dominant consensus tends to obscure and obliterate, aiming to give voice within the existing hegemony. ${ }^{38}$

The intention of an agonist intervention within the public space therefore is not to make a total break with the existing order and suggest an alternative political utopia, but to subvert that order, and provide new subjectivities - i.e. that this sort of art provides a 'potential for transformation' but does not delineate what that transformation should be, or how it should occur. This does not deny art's political role in the social realm, but understands the assumption that "radical art equals transgressive art, and the more radical, the more transgressive" 39 is a false assumption because "there is no transgression that cannot be recuperated by the dominant hegemony." ${ }^{40}$ Rather, the role of critical art is to subvert the hegemonies and disrupt its smooth functioning by bringing to the fore new subjectivities.

These subjectivities should not be based on pre-prescribed politics. I titled this text 'The Artist As Social Worker Vs. The Artist as Social Wanker' as wanted to allude to both the complicated (and/or flawed) notion of the Artist as Social Worker, but also how being a Social Wanker might provide a framework in which participation can bring forth new subjectivities in a more complicated manner. The Oxford English Dictionary (OED) defines 'Wanker' as British vulgar slang for: "a contemptible person." 41 it is mostly employed as a form of generalised abuse, with a reference - albeit not literally - to masturbation. However, I employ it in direct reference to the notion of 'contempt' in that a contemptible person is one who might critique established and accepted modes of power, as in: 'contempt of court'. A wanker, in this reading, is then the one who intentionally operates to unravel and challenge accepted social and cultural patterns. The instrumentalisation of intent - framing participatory artworks as necessarily following a betterment agenda - shuts down the generative possibilities of art and therefore new subjectivities are eradicated. Referencing an impolite and distinctly un-academic swear word within the title aims to replicate the shift in thinking - and intention - that we are required to do to unravel this complicated subject.

This paper has called for a decoding of participatory artworks via the use of clear and specific language to ensure we don't replicate assumption that we all mean the same thing when we say we want to 'work with people'. This clarification of terms allows us to analyse the intentions of public/participatory artwork and through this I argue that any specific ameliorative agenda of participation forecloses the possibility of new political subjectivities, and thus the works exist both in ethically problematic zones (in regards to 'deficit approaches') and also in the binary realm of politics. Artworks in this mode therefore recapitulates simplistic understandings of our pluralistic world. Agonistic participatory practices, in contrast, are useful in being able explore the political, the diverse powers and agencies of the social sphere. They do not aim to fix, but rather do what art does best: ask difficult questions. Asking these difficult questions might go a small way to making the world better, but only in as much as we artists can ask them: l'll leave the actual 'making better' to the professionals.

\footnotetext{
${ }^{38}$ Mouffe, C. (2007) 'Agonistic Politics and Artistic Practices' (Lecture) Glasgow School of Art, Glasgow, 2nd March.

39 Mouffe, C. (2007) 'Agonistic Politics and Artistic Practices' (Lecture) Glasgow School of Art, Glasgow, 2nd March.

40 Mouffe, C. (2007) 'Agonistic Politics and Artistic Practices' (Lecture) Glasgow School of Art, Glasgow, 2nd March.

${ }^{41}$ Oxford English Dictionary Online (n.d.) 'wanker' (https://en.oxforddictionaries.com/definition/wanker) (Available online -

Accessed 22nd Feb, 2017)
} 


\section{References}

Belfiore, E. (2002) 'Art as a means of alleviating social exclusion: Does it really work? A critique of instrumental cultural policies and social impact studies in the UK' International Journal of Cultural Policy, 8:1. pp. 91 106.

Belfiore, E. \& Bennett, O. (2007) Rethinking The Social Impacts of The Arts. International Journal of Cultural Policy, 13:2. pp. $135-151$

Bishop, C.(2012) Artificial Hells: Participatory Art and the Politics of Spectatorship. London: Verso.

Bishop, C. \& Tramontana, S. (eds.) (2009) Double Agent, London: ICA. pp. 99-106

Stevenson, D. (2014) 'Tartan and tantrums: critical reflections on the Creative Scotland "stooshie"'. Cultural Trends, Volume 23, Issue 3, 2014. Special Issue: Scottish Cultural Policy. P 178 -187.

Hewitt, A. (2011) 'Privatising the Public: Three rhetorics of art's public good in 'Third Way' cultural policy' in Art \& the Public Sphere, 1:1, pp. $19-36$.

Hope, S. (2012) Participating in the 'Wrong' Way? Practice Based Research into Cultural Democracy and the Commissioning of Art to Effect Social Change. PhD Thesis. University of London. London.

Kester, G. (1995) 'Aesthetic Evangelists: Conversion and Empowerment in Contemporary Community Art.' in Afterimage Volume 22: Issue 6. (January).

Kester, G. (2000) 'Dialogical Aesthetics: A Critical Framework For Littoral Art' Variant Magazine. Glasgow: Variant, Issue 9. (Special Supplement).

Kester, G. (2004) Conversation Pieces: Community and Communication in Modern Art. Berkeley and Los Angeles, University of California Press.

Maclean, J. (2012) The Open Council: a practice led enquiry into improvisation and the self-institution. PhD Thesis. Newcastle-upon-Tyne. Newcastle University.

Matarasso, F. (2011) 'All in this together': The depoliticisation of community art in Britain, 1970-2011, Community, Art, Power: Essays from ICAF. Rotterdam: ICAF.

Mouffe, C. (2007) 'Agonistic Politics and Artistic Practices'. Lecture delivered at Glasgow School of Art, Glasgow, 2nd March. (http://www.gsa.ac.uk/life/gsa-events/events/c/chantal-mouffe/. (Accessed November 12, 2016)

Mouffe, C. (2013) Agonistics: Thinking The World Politically. London. Verso.

Vickery, J. (2007) The Emergence of Culture-led Regeneration: A policy concept and its discontents. Centre for Cultural Policy Studies, Coventry: University of Warwick.

\section{Web-based References}

Angel Of The North' (2015) Gateshead Government Website, http://www.gateshead.gov. uk/Leisure\%20and\%20Culture/attractions/Angel/Home.aspx. (Available online Accessed 11 December 2016)

Clandestine Insurgent Rebel Clown Army. (n.d.) http://beautifultrouble.org/case/clandestine-insurgent-rebelclown-army/ (Available online - Accessed 11 December 2016)

D. Harding (n.d.) 'The Town Artist'. Undated, David Harding Website: www.davidharding.net/townartist, (Available online - Accessed 1 Jan, 2017).

Liam Gillick (n.d.) Tate Website, http://www.tate.org.uk/art/artists/liam-gillick-2592. (Available online - Accessed 18 May, 2016).

J. Jessen. (n.d) ('Please Love Austria'. Schlingensief Website www.schlingensief.com (Available Online Accessed December 2, 2016)

Oda Projesi (2007). Oda Projesi Website, http://odaprojesi.blogspot.co.uk/. (Available online - Accessed 11 December 2016).

Palas Por Pistolas. (n.d.) http://pedroreyes.net/palasporpistolas.php, (Available online - Accessed 16 October 2016)

S. Sherwin, '(2010) Artist of the Week 101: Artur Zmijewski' The Guardian Website http://www.theguardian.com/artanddesign/2010/aug/18/artist-of-week-artur-zmijewski (Available Online Accessed May 15, 2016)

The International Federation of Social Work (n.d.) http://ifsw.org/get-involved/global-definition-of-social-work/ (Available Online - Accessed Feb 10th, 2017) 